\title{
Determination of heavy metals in Pleurotus ostreatus (Oyster mushroom) and Termitomyces clypeatus (Termite mushroom) sold on selected markets in Accra, Ghana
}

\author{
Quarcoo $A^{\mathbf{1}}$ and Adotey $\mathbf{G}^{\mathbf{1}}$ \\ ${ }^{1}$ Accra Polytechnic, Science Laboratory Technology Department, Box GP 561, Accra. \\ Email: niiaqua@yahoo.com
}

Quarcoo A, Adotey G 2013 - Determination of heavy metals in Pleurotus ostreatus (Oyster mushroom) and Termitomyces clypeatus (Termite mushroom) sold on selected markets in Accra, Ghana. Mycosphere 4(5), 960-967, Doi 10.5943/mycosphere/4/5/9

\begin{abstract}
This study was conducted to determine the presence and concentration of heavy metals $\mathrm{Cd}$, $\mathrm{Fe}, \mathrm{Pb}, \mathrm{As}$, and $\mathrm{Hg}$ in Pleurotus ostreatus (oyster mushroom), and Termitomyces clypeatus (termite mushroom) from markets in Greater Accra region (Kaneshie market, Madina market and Makola market), Ghana by using VARIAN AA240 FS- Atomic Absorption Spectroscopy (AAS). The levels of heavy metals in the P.ostreatus, and T.clypeatus ranges from 0.35 to $0.57 \mathrm{mg} / \mathrm{kg}$ for $\mathrm{Cd}, 43.77$ to $65.19 \mathrm{mg} / \mathrm{kg}$ for $\mathrm{Fe}, 0.04$ to $0.23 \mathrm{mg} / \mathrm{kg}$ for $\mathrm{Pb}, 0.04$ to $0.10 \mathrm{mg} / \mathrm{kg}$ for As and 0.04 to $0.04 \mathrm{mg} / \mathrm{kg}$ for Hg. T.clypeatus was observed to have the highest concentration of all the heavy metals. While cadmium and mercury were above the recommended limits set by organizations like the European Commission and the WHO/FAO Expert Committee on Food Additives, none of the values obtained here are considered health risks because of the large amounts of these mushrooms that must be consumed for heavy metal toxicity to kick in.
\end{abstract}

Key words - atomic absorption - spectroscopy - heavy metals - mushrooms - Pleurotus ostreatus - Termitomyces clypeatus

\section{Introduction}

Ghana is a tropical country with moderate to high rainfall conditions that are very suitable for the growth of all kinds of mushrooms. Mushrooms are a delicacy in Ghana and although a number of people have started cultivating these mushrooms (particularly Pleorotus ostreatus), most of the mushrooms on sale on the open market are seasonal in nature, including Termitomyces clypeatus. Most research done on mushrooms in Ghana have focused on the challenges of cultivation of the oyster mushroom (Pleurotus ostreatus) (Narh, Obodai 2009; Achio et. al. 2009 and Sarpong et. al. 2009).

Mushrooms are consumed for various reasons. Apart from their delicious taste, most people in Ghana are becoming aware of their medicinal properties. Indeed most mushrooms, including Pleorotus spp., and Termitomyces are known to possess medicinal properties. Pleurotus spp. has been proven to have anticholesterolemic and antioxidant properties (Anandhi et. al. 2013), blood lipid lowering effects ( $\mathrm{Hu}$ et. al. 2006), antihepatoma and antisarcoma activities (Wang and Gao, 
2000) among others. Termitomyces clypeatus has also demonstrated plasma lipid lowering effects (Oyetayo, 2006), Termitomyces is also a good source of sugar, protein, fiber, lipid, vitamins, and minerals in addition to medicinal values such as lowering blood pressure, rheumatism, kwashiorkor, obesity, diarrhea and as a purgative (Apetorgbor et. al. 2005). It also has immunostimulatory properties (Maiti et.al. 2008).

The presence of heavy metals in soil, air, water, and living objects is a major public health concern and due to their detrimental effects on man and the environment, their removal from the environment is deemed important to the protection of environmental health. Heavy metals are dangerous because they tend to bioaccumulate, a process whereby an increase in the concentration of a chemical in a biological organism takes place over time, compared to the chemical's concentration in the environment. Compounds accumulate in living things any time they are taken up and stored faster than they are broken down (metabolized) or excreted (http://extoxnet.orst.edu/tibs/bioaccum.htm).

Unlike many organic wastes, heavy metals cannot be degraded biologically to harmless products. Mushrooms absorb heavy metals from a substrate via spacious mycelium. Age and the size of the fruiting body are of less importance. The proportion of the metal contents originating from the atmospheric depositions seems to be also of less importance due to the short lifetime of a fruiting body, which is usually 10-14 days (Pavel et. al. 2004). Mushrooms, compared to green plants, are capable of bio-accumulating more heavy metals in their fruit bodies since some of these heavy metals are natural components of the earth's crust. It has been found that mushrooms can bio-accumulate many molecules because of the mycelial structures they posses (Demirbas 2000).

Concentrations of heavy metals have been observed in the fruiting bodies of mushrooms collected adjacent to heavy metal smelters (Kalac et. al. 1996), and landfills of sewage sludge emission areas (Cibulka et. al. 1996). The mushroom industry has been viable since the 1990s in Ghana. The main substrates used in the commercial production of mushrooms in Ghana include rice straw, cotton seed waste, aquatic weeds and sawdust from trees such as Triplochiton scleroxylon (locally known as 'wawa') from mixed redwood of Terminali aivorensis (emire) and Chlorophora excela (odum) (Obodai et. al. 2000). Some species of mushrooms uniquely grow on mounds of termites and ants.

There is enough research on the nutritional and therapeutic values of mushrooms whilst there is little or no information on its heavy metals bio-accumulation in Ghana. The objectives of this work are therefore to determine the heavy metal content of mushrooms from some major markets in Ghana and their safety as to compliance to standards set by the Food and Agriculture Organization (FAO) and other international tolerance limits on heavy metals in food. It will also begin the process of building a valuable source of information on heavy metals in mushrooms in Ghana.

\section{Materials and Methods \\ Study area and place of analysis}

The study area includes some key markets found in the Greater Accra region (Kaneshie market, Madina market and Makola market). These markets were chosen because they are the leading markets for residents of western, northern and southern parts of the city of Accra respectively. The Kaneshie market is located on the trunk road from Accra to the western parts of the country. Madina central market is found in the Ga East District of the Greater Accra Region of Ghana, while the Makola market is the biggest market place in the country located in the central business district of the city of Accra. Mushrooms sold on these markets are brought in from surrounding towns and villages in the Greater Accra region, as well as other surrounding regions. The sampled species of mushroom was analyzed for their heavy metal content in the chemistry department of the Ghana Atomic Energy Commission (GAEC).

\section{Study period}

Sampling was done for one week followed by two weeks of analysis and data tabulation. 


\section{Samples, sampling technique and size}

The samples for the research includes; Pleurotus ostreatus (oyster mushroom), and Termitomyces clypeatus (termite mushrooms). The simple random sampling technique was used to select the different species of mushroom from sellers of the particular species on the markets. Five samples each of $P$. ostreatus and $T$. clypeatus were bought from randomly selected market women in each market place on three different days, giving a total of thirty (30) samples.

\section{Sampling}

Each of the two species of mushrooms was placed in a polythene bag and labeled with the name of the market it was sampled from, species name, as well as sampling date. The labeled bag with samples was stored in a freezer, for the first week. The mushroom species were identified by staff of the mushroom unit of the Ghana Food Research Institute based on microscopic and morphological characteristics of the mushrooms according to methods set out by Pegler (1977), Phillips (1981), Courtecuisse and Duhom (1995), Laessoe (1998), and Ryvarden and Johansen (1980).

\section{Digestion and working standard preparation}

In the analysis of heavy metals in mushroom with Atomic Absorption Spectrometer (AAS), the following digestion protocol was used.

The two different species of mushrooms; P. ostreatus, and T. clypeatus, were bought from each of the three identified markets. Each mushroom species was individually cleaned, cut into pieces and placed in a labeled special glass container and then freeze dried under high pressure. The dried mushroom sample was thoroughly blended into powdered form. $0.50 \mathrm{~g}$ of the milled samples was weighed into Teflon beakers. Six (6) $\mathrm{ml}$ of concentrated $\mathrm{HNO}_{3}(65 \%)$ and $1 \mathrm{ml}$ of $\mathrm{H}_{2} \mathrm{O}_{2}(30 \%)$ were added to the samples, covered tightly in Teflon bombs and loaded onto the rotor using the wrench or torque in the fume chamber. The rotor with the Teflon bombs was placed in the ETHOS 900 Microwave Digester and digested using the Microwave Programme (Report Code: 183). The complete assembly was microwaved for 25 minutes using Milestone Microwave Lab Station ETHOS 900, MLS-1200. After digestion the Teflon bombs mounted on the microwave carousel were cooled in a water bath to reduce internal pressure and allow volatilized material to restabilize. The digestate was made up to $20 \mathrm{ml}$ with double distilled water and assayed for the presence of iron $(\mathrm{Fe})$, lead $(\mathrm{Pb})$, mercury $(\mathrm{Hg})$, cadmium $(\mathrm{Cd})$ and Arsenic (As) using VARIAN AA240 FS-Atomic Absorption Spectrometer in an acetylene air flame. The reference standards for each of the elements of interest, blanks and duplicates of the samples were digested under the same condition as the samples. These served as internal positive controls. Reference standard used was from FLUKA ANALYTICAL, Sigma-Aldrich Chemie GmbH, Switzerland.

\section{Statistical tool and analysis employed}

The Student $t$-test was the statistical tool used to estimate the statistical significances at $95 \%$ Confidence Interval.

\section{Results}

The means and comparative concentrations of various heavy metals for the two mushroom species are summarized in Table 1.

The concentrations of heavy metals for P. ostreatus ranged from $0.04,0.04,42.56-44.56$, $0.16-0.68$ and $0.04 \mathrm{mg} / \mathrm{kg}$ respectively for lead, arsenic, iron, cadmium and mercury.

The concentrations of heavy metals for $T$. clypeatus ranged from $0.04-0.06,0.08-0.14$, 55.72-73.46, 0.08-0.88, and $0.04 \mathrm{mg} / \mathrm{kg}$ respectively for lead, arsenic, iron, cadmium and mercury.

The order of concentrations of heavy metals in $P$. ostreatus was found to be $\mathrm{Fe}>\mathrm{Cd}>\mathrm{Pb}, \mathrm{As}$, $\mathrm{Hg}$, and for T. clypeatus was $\mathrm{Fe}>\mathrm{Cd}>\mathrm{Pb}>\mathrm{As}>\mathrm{Hg}$.

All the heavy metal concentration values for $T$. clypeatus were greater than those of $P$. ostreatus. 
Table 1 Mean concentrations (mg/kg) of heavy metals in P.ostreatus and T. clypeatus

\begin{tabular}{lccccc}
\hline \multicolumn{2}{l}{ Mushroom Species $\mathbf{P b}^{*}$} & $\mathbf{A s}^{\dagger}$ & $\mathbf{F e}^{\ddagger}$ & $\mathbf{C d}^{\mathbf{\alpha}}$ & $\mathbf{H g}$ \\
\hline P. ostreatus & 0.04 & 0.04 & 43.77 & 0.35 & 0.04 \\
& & & & & \\
T. clypeatus & 0.23 & 0.10 & 65.19 & 0.57 & 0.04 \\
\hline
\end{tabular}

* No significant difference in the $\mathrm{Pb}$ content at $5 \%$ significant level $\mathrm{p}=0.374$

$\uparrow$ Statistically significant difference in the As content at $5 \%$ significant level $\mathrm{p}=0.040$

+ Statistically significant difference in the Fe content at $5 \%$ significant level $\mathrm{p}=0.015$

$\alpha$ No statistically significant difference in the $\mathrm{Cd}$ content at $5 \%$ significant level $\mathrm{p}=0.492$

\section{Discussion}

Lead $(\mathrm{Pb})$ as observed in T.clypeatus $(0.23 \mathrm{mg} / \mathrm{kg})$ was higher in concentration than P.ostreatus whose $\mathrm{Pb}$ concentration was $0.04 \mathrm{mg} / \mathrm{kg}$ (Table 1). An independent sample $\mathrm{T}$ - test performed at $95 \%$ Confidence Interval revealed no statistically significant difference between the lead content in $T$. clypeatus and that of $P$. ostreatus since $\mathrm{p}>0.05$.

The EU maximum permitted level for lead in cultivated mushrooms is $0.3 \mathrm{mg} / \mathrm{kg}$ wet weight (European Commission, 2001). The values thus obtained are acceptable as they all fall within these limits. $\mathrm{Pb}$ finds its way into the environment as constituent of pesticides and industrial waste release into the environment, such as used car batteries, alloys, solder, broken ceramics and plastics. Another source is the exhaust fumes of car using leaded fuel, though that threat is now greatly reduced as most cars use unleaded fuel. Target organs where it can be accumulate in the body are the bones, brain, blood, kidneys, and thyroid gland. Lead has no benefit to human metabolism. Gradual accumulation can lead to lead poisoning. This may lead to high blood pressure, muscular weakness, and headaches among others. The ranges detected for lead fall within what is generally detected from mushrooms in the literature. These include Tuzen et. al. (1998), who detected a range of $0.75-7.77 \mathrm{mg} / \mathrm{kg}$; Svoboda et. al. 2000, who detected a range of $0.40-2.80 \mathrm{mg} / \mathrm{kg}$ and then Türkekul et. al. 2004, who detected a range of $0.800-2.700 \mathrm{mg} / \mathrm{kg}$, all in edible mushrooms.

The mean result obtained from the laboratory analysis also showed the presence of arsenic in the two species of mushrooms T.clypeatus and P.ostreatus. P.ostreatus recorded a concentration of $0.04 \mathrm{mg} / \mathrm{kg}$ of arsenic which was lower than T.clypeatus with a concentration of $0.10 \mathrm{mg} / \mathrm{kg}$ (Table 1). An independent sample $\mathrm{T}$ - test performed at $95 \%$ Confidence Interval revealed a statistically significant difference between the arsenic content in $T$. clypeatus and that of $P$. ostreatus since $\mathrm{p}<0.05$.

In research carried out in Finland, the greatest amount of Arsenic was found in the mushroom Agaricus abruptibulbus, which contains $0.51 \mathrm{mg} / \mathrm{kg}$ fresh weight. The Joint FAO/WHO Expert Committee on Food Additives (JECFA) has established a Provisional Tolerable Weekly Intake (PTWI) of $0.015 \mathrm{mg} / \mathrm{kg}$ body weight allowing $0.9 \mathrm{mg}$ of arsenic to be consumed weekly by a person of $60 \mathrm{~kg}$ in weight. As $1.76 \mathrm{~kg}$ of fresh A. abruptibulbus could be eaten per week without exceeding the PTWI value, no significant risk of excess arsenic intake is seen to arise from the consumption of the studied mushroom species here (Riina et. al. 2006). Hence T.clypeatus and P.ostreatus used in this research can be safely consumed.

Iron $(\mathrm{Fe})$ concentration was observed to be high in T.clypeatus $(65.19 \mathrm{mg} / \mathrm{kg}$ ) and lower in P.ostreatus $(43.77 \mathrm{mg} / \mathrm{kg}$ ) (Table 1). An independent sample T- test performed at $95 \%$ Confidence Interval revealed a statistically significant difference between the Iron content found in $T$. clypeatus and that of $P$. ostreatus since $\mathrm{p}<0.05$.

Iron had the highest concentration of all the heavy metals analyzed. Iron is an essential trace element for humans due to its necessity in haem proteins such as hemoglobin, myoglobin and cytochromes. Iron deficiency is common and leads to iron-deficiency, anemia. The Recommended Daily Intake of iron is $15 \mathrm{mg} /$ day. Consumption of these mushrooms will therefore serve as a very good source of iron supplementation particularly in low income countries where iron deficiency 
anemia is a serious heath challenge. Reported values for iron in mushrooms are usually high (Nuorteva et. al. 1986; Falandysz et. al. 2001; Tyler 1980 ). This may be due to its abundance on earth.

The concentrations of Cadmium $(\mathrm{Cd})$ observed in the P.ostreatus, and T.clypeatus are shown in Table 1. A higher concentration of Cd was seen in T.clypeatus $(0.57 \mathrm{mg} / \mathrm{kg})$ as compared to P.ostreatus which recorded a concentration of $0.35 \mathrm{mg} / \mathrm{kg}$. An independent sample T- test performed at $95 \%$ Confidence Interval revealed no statistically significant difference between the cadmium content found in Termitomyces clypeatus and that of Pleurotus ostreatus since $\mathrm{p}>0.05$.

The EU has set a maximum permitted level ( $\mathrm{mg} / \mathrm{kg}$ wet weight) for cadmium and lead in cultivated mushrooms but no legislative standards are as yet set for arsenic and nickel in similar food products by the EU (European Commission, 2001). The limit set for Cd by the European Commission was $0.2 \mathrm{mg} / \mathrm{kg}$ wet weight. Cadmium might have found its way into the mushrooms as impurity in several products, including phosphate fertilizers, insecticides, fungicides, detergents and refined petroleum products introduced into the environment in which the mushrooms grows. Cadmium is also a natural element in the earth's crust. It is usually found as a mineral combined with other elements such as oxygen (cadmium oxide), chlorine (cadmium chloride), or sulphur (cadmium sulphate, cadmium sulphide). Cadmium is known as a principal toxic metal, since excessive cadmium exposure may give rise to renal, pulmonary, hepatic, skeletal, reproductive effects, and cancer. It was reported that cadmium is accumulated mainly in kidneys, spleen, and liver, and its blood serum level increases considerably following mushroom consumption (Kala c and Svoboda 2001). Thus, cadmium seems to be the most deleterious among heavy metals in mushrooms (Pavel et. al. 2004). The WHO mentions maximum permissible levels in raw plant materials for cadmium as $0.30 \mathrm{mg} / \mathrm{kg}$. Clearly, both P.ostreatus and T.clypeatus recorded values above this permissible limit. This may imply that consumption of these mushrooms from the locality they were harvested in large amounts may lead to deleterious effects in health if consumed continuously in large amounts. However, given the relatively small amounts consumed by the average person, it is unlikely to pose any serious health challenges.

The concentration of Mercury $(\mathrm{Hg})$ observed in T.clypeatus and P.ostreatus was $0.04 \mathrm{mg} / \mathrm{kg}$ (Table 1). At $\mathrm{p}<0.05$, there is no statistically significant difference between mercury values for $T$. clypeatus and that of $P$. ostreatus.

The tolerance limit of total mercury concentration in fresh vegetables, potatoes and processed vegetables is $0.02 \mathrm{mg} / \mathrm{kg}$ wet weight i.e. $20 \mathrm{ng} / \mathrm{g}$, while in dried (> 50\% dry matter) plant food is $0.03 \mathrm{mg} / \mathrm{kg}$ i.e. $30 \mathrm{ng} / \mathrm{g}$ (Zurera et. al. 1986 ). Chronic exposure to methyl mercury can cause damage to the nervous system. In adults the earliest signs of toxicity include paraesthesia, ataxia and blurred vision. With respect to neurotoxicity the fetus is the most vulnerable: there is evidence of developmental retardation in children whose mothers were exposed to methyl mercury during pregnancy (WHO 1990 \& Alfthan et. al. 1994). The 'no observed adverse effect level' (NOAEL) for methyl mercury, is $0.24 \mathrm{mg} /$ week. Hence it can be said that these mushrooms are safe for consumption (Riina et. al. 2008). However, in mushrooms, methyl mercury makes up less than $10 \%$ of the total mercury (Stijve \& Besson, 1976). As inorganic $\mathrm{Hg}$ is less toxic than methyl mercury, the recommended amount for mushroom consumption with respect to methyl mercury may be assumed to be somewhat higher. The results as obtained here may therefore pose no danger to consumers.

From the results in Table 1, it is clear that T. clypeatus has the highest concentration of all the heavy metals. This may be due to the fact that there is a symbiotic relationship between $T$. clypeatus and the termites as described by Aanen DK 2006. It is our view that over several generations of this symbiotic relationship, the concentration of heavy metals in the termite mounds increases as a result of accumulation of termite waste. Since these mushrooms obtain their nourishment from this environment, they end up having higher concentrations of the metals available. On the other hand, $P$. ostreatus is basically parasitic in nature, and acts as a primary decomposer of wood (Phillips R. 2006) that may not contain these heavy metals in high 
concentrations. The observed pattern may just be a reflection of how each species absorbs metals as determined by their genetic makeup (Pavel K. et. al. 2004).

\section{Conclusion}

In general, it can be said that the amounts of $\mathrm{Pb}, \mathrm{As}, \mathrm{Fe}, \mathrm{Cd}$, and $\mathrm{Hg}$ in these mushrooms purchased from various markets in Accra are safe for consumption as the values are in consonance with previously published figures from other works. The values also generally fall in line with recommendations by international organizations like the European Commission and the WHO/FAO Expert Committee on Food Additives. Iron had a significantly high concentration in all three mushroom species because iron is the most abundant element in the universe.

It is important to note that the mean intake from food and the environment may be considerably large for many elements. According to JECFA the safety margin between the exposure in a normal diet and the level causing adverse health effects may thus be relatively small (Council of Europe 2001).

\section{References}

Aanen DK 2006 - As you reap, so shall you sow: coupling of harvesting and inoculating stabilizes the mutualism between termites and fungi. Biol. Lett. 2006(2), 209-212 doi: $10.1098 / \mathrm{rsbl} .2005 .0424$

Achio SM, Obodai, and Mortu S. 2009 - Effect of storage temperature and packaging on the keeping qualities of fresh oyster mushroom (Pleurotus ostreatus). In: Proceedings of the 2nd African Conference on Edible and Medicinal Mushrooms. Noguchi Memorial Institute for Medical Research, Accra, Ghana. 24th- 28th March, 2009 CSIR- FRI/CP/AS/2009/003

Alfthan G, Männistö S, Valsta L \& Pietinen P. 1994 - Naisten altistuminen ravinnon elohopealle Suomessa. Elintarvikevirasto, Helsinki. Elintarvikeviraston tutkimuksia 1/1994.

Anandhi R, Annadurai T, Anitha TS, Muralidharan AR, Najmunnisha K, Nachiappan V, Thomas PA, Geraldine P. 2013 - Antihypercholesterolemic and antioxidative effects of an extract of the oyster mushroom, Pleurotus ostreatus, and its major constituent, chrysin, in Triton WR1339-induced hypercholesterolemic rats. J Physiol Biochem. 69(2), 313-23. doi: 10.1007/s13105-012-0215-6.

Apetorgbor MM, Apetorgbor AK, Nutakor E. 2005 - Utilization and cultivation of edible mushrooms for rural livelihood in Southern Ghana. 17th Commonwealth Forestry Conference, Colombo, Sri Lanka.

Cibulka J, Sisak L, Pulkrab K, Miholova D, Szakova J, Fucikova A et. al. 1996- Cadmium, lead, mercury and caesium levels in wild mushrooms and forest berries from different localities of the Czech Republic. Scientia Agriculturae Bohemica 27, 113- 129.

Council of Europe. 2001 - Policy Statement concerning metals and alloys. Guidelines on Metals and Alloys Used as Food Contact Material. Council of Europe, EU.

Courtecuisse, R. and Duhom B. 1995 - Mushrooms and Toadstools of Britain and Europe. Collins Field Guide. Harper Collins Publishers, London.

Demirbas A 2000 - Accumulation of heavy metals in some edible mushrooms from Turkey. Food Chemistry 68, 415-419.

European Commission. 2001 - Commission Regulation (EC) No 466/2001. Directive 2001/22/EC. European Commission, EU.

Falandysz J, Szymczyk K, Ichihashi H, Bielawski L, Gucia M, Frankowska A, Yamasaki S. 2001 ICP/MS and ICP/AES elemental analysis (38 elements) of edible wild mushrooms growing in Poland. Food Addit Contam. 18(6) 503-513.

http://extoxnet.orst.edu/tibs/bioaccum.htm.

Hu SH, Liang ZC, Chia YC, Lien JL, Chen KS, Lee MY, Wang JC. 2006 - Antihyperlipidemic and antioxidant effects of extracts from Pleurotus citrinopileatus. J Agric Food Chem. 54(6), 2103-10. 
Kala c, P, Svoboda, L. 2001 - A review of trace element concentrations in edible mushrooms. Food Chemistry 69, 273-281.

Kalac P, Niznanska M, Berilaqua D, and Staskova I. 1996 - Concentrations of mercury, copper, cadmium and lead in the fruiting bodies of edible mushrooms in the vicinity of a mercury smelter and copper smelter. Sci. Tot. Env. 177, 251-8.

Laessoe, T 1998 Mushrooms - The Visual Guide to over 500 species of Mushrooms from around the world. Darling Kindersley Ltd, London.

Maiti S, Bhutia SK, Mallick SK, Kumar A, Khadgi N, Maiti TK. 2008 - Antiproliferative and immunostimulatory protein fraction from edible mushrooms. Environ Toxicol Pharmacol. 26(2):187-91. doi: 10.1016/j.etap.2008.03.009.

Narh DL and Obodai M. 2009 - Comparative utilization of rice straw on the growth and yield of three Pleurotus species. In: Proceedings of the 2nd African Conference on Edible and Medicinal Mushrooms. Noguchi Memorial Institute for Medical Research, Accra, Ghana. 24th-28th March, 2009 CSIR- FRI/CP/NDL/2009/002.

Nilanjana D 2005 - Heavy metals biosorption by mushrooms. Nat. Prod. Rad. 4(6) 454-459.

Nuorteva P, Autio S, Lehtonen J, Lepistö A, Ojala S, Seppänen A, Tulisalo E, Veide P, Viipuri J, \& Willamo R. 1986 - Levels of iron, aluminium, zinc, cadmium and mercury in plants growing in the surroundings of an acidified and a non- acidified lake in Espoo, Finland. Ann Bot Fenn. $23,333-340$.

Obodai M, Sawyerr LCB, and Johnson PNT 2000 - Yield of seven strains of oyster mushrooms (Pleurotus spp.) grown on composted sawdust of Triplochiton scleroxylon. Tropical Science 40 (2), 95- 99.

Oyetayo, FL. 2006 - Responses of plasma lipids to edible mushroom diets in albino rats. African Journal of Biotechnology Vol. 5 (13), pp. 1263- 1266, 3 July 2006.

Pavel K, Lubomír S, Božena H. 2004 - Contents of detrimental metals mercury, cadmium and lead in wild growing edible mushrooms, A review. Energy Education Science and Technology 13(1), 31- 38

Pegler, DN 1977 - A preliminary Agaric. Flora of East Africa. Kew Bulletin Additional Series 6:1 $-615$.

Phillips R. 2006 - Mushrooms. Pub. McMillan, ISBN 0-330-44237- 6. P. 266.

Phillips, R. 1981 - Mushrooms and Other Fungi of Great Britain and Europe. Pan Books Ltd. London.

Riina P, Georg A, and Olli J. 2006 - Cadmium, lead, arsenic and nickel in wild edible mushrooms. The Finnish Environment 17, 32.

Riina P, Georg A, Olli J. 2008 - Element concentrations in wild edible mushrooms in Finland. The Finnish Environment. 25, 32.

Ryvarden, L and Johansen I. 1980 - A preliminary polypore flora of East Africa. Oslo

Sarpong NS, Adamafio NA, Obodai M. 2009 - Stability of Pleurotus ostreatus strain EM- 1 laccase: Determination of optimum concentrations of glycerol and metal ions. In: Proceedings of the 2nd African Conference on Edible and Medicinal Mushrooms. Noguchi Memorial Institute for Medical Research, Accra, Ghana. 24th- 28th March, 2009 (Poster presentation) CSIR- FRI/CP/SNS/2009/004

Seeger R, Schiefelbein F, Seuffert R, Zant W. 1986 - Absorption of cadmium ingested with mushrooms. Naunyn's- Schmiedeberg's Arch Pharmacol 1986 - 332, Suppl. abstract 110.

Stivje T, Besson R. 1976 - Mercury, cadmium, lead and selenium content of mushroom species belonging to the genus Agaricus. Chemosphere 2, 151-158.

Svoboda L, Zimmermannova K, Kalac P. 2000 - Concentrations of mercury, cadmium, lead and copper in fruiting bodies of edible mushrooms in an emission area of a copper smelter and a mercury smelter. Science of the Total Environment 246, 61-67.

Türkekul I, Elmastas M, Tüzen M. 2004 - Determination of iron, copper, manganese, zinc, lead, and cadmium in mushroom samples from Tokat, Turkey. Food Chemistry 84, 389-392. 
Tüzen M, Ozdemir M, Demirbas. A 1998 - Study of heavy metals in some cultivated and uncultivated mushrooms of Turkish origin. Food Chemistry 63, 247-251.

Tyler G. 1980 - Metals in sporophores of basidiomycetes. Transactions of the British Mycological Society 74(1), 41-49.

Wang H, Gao J, Ng TB. 2000 - A new lectin with highly potent antihepatoma and antisarcoma activities from the oyster mushroom Pleurotus ostreatus. Biochem Biophys Res Commun. Sep 7;275(3), 810-816.

WHO 1990 - Methylmercury. Environmental Health Criteria 101. World Health Organization, Geneva.

Zurera G, Rincon F, Arcos F, Pozo- Lora R. 1986 - Mercury content in mushroom species in the Cordoba area. Bull. Environ. Contam. Toxicol. 36, 662. 